\title{
MUTU KEJU PUTIH RENDAH LEMAK DIPRODUKSI DENGAN BAHAN BAKU SUSU MODIFIKASI
}

\section{QUALITY OF LOW FAT WHITE CHEESE PRODUCED USING RAW MATERIAL OF MODIFIED MILK}

\author{
Abubakar* dan Sri Usmiati \\ Balai Besar Litbang Pascapanen Pertanian, Bogor, 16114
}

Submitted: 26 January 2016, Accepted: 16 May 2016

\section{INTISARI}

\begin{abstract}
Penelitian ini dilakukan untuk mengetahui mutu keju putih rendah lemak yang diproduksi menggunakan bahan baku susu modifikasi. Lima macam perlakuan digunakan dalam pembuatan keju putih dengan mengurangi lemak berdasarkan modifikasi susu (A). Perlakuan (A1) mengurangi kandungan lemak susu sebesar 60\%, (A2) Emulsi minyak jagung dalam susu skim (menggantikan lemak susu dengan lemak nabati, minyak jagung), (A3) Emulsi minyak jagung dalam susu skim dengan penambahan whey protein concentrate (WPC), (A4) menggunakan Susu skim + emulsi $\mathrm{W}_{1} \mathrm{OW}_{2}$, dan (A5) mengganti lemak susu dengan lemak nabati (minyak jagung) dengan penambahan probiotik (Lactobacillus casei). Masing-masing perlakuan dengan 3 ulangan. Hasil penelitian menunjukkan bahwa susu skim dalam emulsi minyak jagung dengan penambahan probiotik mempunyai karakteristik keju sebagai berikut rendemen $12,94 \pm 0,16 \%$,

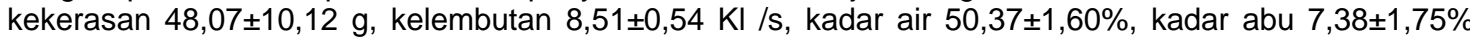
(bahan kering), kadar lemak 41,06 $\pm 6,07 \%$ (bahan kering), kadar protein 37,85 $\pm 3,25 \%$ (bahan kering), kadar fosfor 346,62 $25,61 \mathrm{mg} / 100 \mathrm{~g}$ (bahan kering), kadar kalsium 860,78 $\pm 87,91 \mathrm{mg} / 100 \mathrm{~g}$ (bahan kering), warna putih, tekstur biasa, tidak beraroma, rasa asin, lembut, elastis, dan tingkat preferensi biasa.
\end{abstract}

(Kata kunci: Keju putih, Rendah lemak, Kualitas, Susu modifikasi)

\section{ABSTRACT}

This research was conducted to investigate the quality of low-fat white cheese produced using raw material of modified milk. Five treatments applied were (A1) Using reduced fat (60\%) milk, (A2) Using emulsion of corn oil in skim milk (replacing milk fat with corn oil), (A3) Using emulsion of corn oil in skim milk and addition of whey protein concentrate (replacing milk fat with corn oil and the addition of whey protein concentrate=WPC), (A4) Using skim milk and water emulsion oil in water, and (A5) replacing milk fat with corn oil and the addition of probiotic (Lactobacillus casei). Each treatment was replicated three times. The selected that skim milk in corn oil emulsion with the addition of probiotics, the results showed had cheese quality characteristics as follow: yield $12.94 \pm 0.16 \%$, hardnes $48.07 \pm 10.12 \mathrm{~g}$, softness $8.51 \pm 0.54 \mathrm{~kg} / \mathrm{s}$, moisture content $50.37 \pm 1.60 \%$, ash content $7.38 \pm 1.75 \%$ (dry matter), fat content $41.06 \pm 6.07 \%$ (dry matter), protein content 37.85 $\pm 3.25 \%$ (dry matter), phosphorus content 346.62 \pm 25.61 $\mathrm{mg} / 100 \mathrm{~g}$ (dry matter), calcium content $860.78 \pm 87.91 \mathrm{mg} / 100 \mathrm{~g}$ (dry matter), white color, regular texture, not flavorfull, salty taste, soft texture, elastic, ordinary preference acceptance.

(Key words: Low fat, Modified milk, Quality, White cheese)

\section{Pendahuluan}

Saat ini makanan siap saji sangat banyak dan beragam baik sebagai makanan pokok maupun sebagai makanan pendamping/snack. Pada umumkan makanan siap saji mempunyai kolori dan lemak tinggi dan sangat disukai masyarakat perkotaan.
Salah satu makanan yang digemari masyarakat di perkotaan adalah keju. Keju merupakan salah satu produk olahan susu yang memiliki kandungan gizi yang lengkap dan seimbang. Keju mempunyai beberapa keunggulan dibanding susu segar, di antaranya, kandungan gizi keju tidak kalah dengan susu segar, dapat dikonsumsi oleh masyarakat yang menderita lactose intolerance, dan mengandung protein dengan

\footnotetext{
* Korespondensi (corresponding author)

Telp +62 85772599704

E-mail: abu.028@gmail.com
} 
asam-asam amino esensial yang dibutuhkan oleh tubuh. Keju merupakan satu-satunya bahan pangan yang mempunyai daya simpan yang baik dan kaya akan protein, lemak, kalsium, fosfor, besi, riboflavin, dan berbagai jenis vitamin (kecuali vitamin C yang mengalami kerusakan saat pengolahan). Kandungan gizi pada $100 \mathrm{~g}$ keju yaitu, 22,8 g protein, 25,5 g lemak, 0,4 $\mathrm{mg}$ zat besi, 0,06 mg vitamin B1, 155 RE vitamin A, dan 285 Cal energi (San et al., 2007; El-Bakry et al., 2011). Terdapat ratusan bahkan ribuan keju yang beredar dan dikonsumsi oleh masyarakat dunia. Salah satu jenis keju yang populer adalah keju lunak yang klasifikasinya didasarkan atas kadar air. Keju dengan kadar air lebih kecil 40\% disebut dengan keju lunak. Keju lunak terbagi dalam beberapa jenis, salah satunya adalah keju putih. Keju putih merupakan keju tanpa pemeraman dengan kandungan lemak yang rendah (Abdulmalek dan Abdulaziz, 2011; Ana et al., 2012). Tingginya kandungan lemak pada keju mengakibatkan keju ini banyak dihindari oleh masyarakat, untuk itu diperlukan usaha dalam menurunkan kadar lemak keju namun tidak mengurangi karakteristik mutu keju. Keju yang diproduksi dari susu penuh (whole milk) mempunyai kandungan lemak yang tinggi, agar dapat dikonsumsi oleh masyarakat yang mulai peduli terhadap kesehatan, maka perlu upaya untuk menurunkan kadar lemak tersebut. Salah satu cara dalam menurunkan kandungan lemak keju namun tidak mengurangi kualitas adalah dengan melakukan modifikasi terhadap bahan baku susu sapi. Modifikasi yang dapat dilakukan di antaranya yaitu, menurunkan kadar lemak, atau juga dapat mengganti lemak susu sapi dengan minyak nabati dalam sistem emulsi water in oil in water (W1OW2) atau mengganti lemak susu dengan fat replacer (pengganti lemak) yang mempunyai efek fungsional produk setara dengan lemak. Oleh karena itu perlu dilakukan penelitian mengenai mutu keju putih rendah lemak menggunakan berbagai bahan baku susu sapi modifikasi (pengganti lemak).

\section{Materi dan Metode}

Penelitian ini telah dilakukan di Laboratorium Pascapanen Hasil Pertanian Balai Besar Penelitian dan Pengembangan Pascapanen Pertanian, Bogor. Bahan-bahan yang digunakan: susu skim segar dari peternakan Konak Leuwiliang, enzim rennet komersial (merk marschall), starter
Streptococcus lactis, Lactobacillus casei (Koleksi Balai Besar Litbang Pascapanen Petanian, Bogor), $\mathrm{CaCl}_{2}$, Whey Protein Concentrate (WPC), gellan gum (merk gellangummi, ApliChem), minyak jagung (merk Chines Corn Oil (CCO), polioksietilen sorbitan monostearat/Tween-60 (merk Merck, Merck Schuchardt OHG-Jerman), sorbitan monostearat/span-60 (merk Kosteran S/I, PT Perdoni-Jakarta), gliserol monostearat/GMS (merk Chitrol GMS 0402, PT Setia Agung Kimia-Jakarta), sorbitol, carboxymethyl cellulose (CMC) dibeli dari PT Setia GunaBogor, medium chain trigliserid (MCT), garam dapur dan bahan-bahan yang digunakan untuk analisis kualitas susu dan keju.

\section{Proses modifikasi bahan baku}

Penurunan lemak susu sebanyak

60\% (A1). Penurunan lemak sebanyak 60\% dilakukan dengan cara menambahkan krim susu ke dalam susu skim yang telah dibuat hingga susu memiliki kadar lemak sebanyak $40 \%$. Berdasarkan hasil analisis kadar lemak pada susu segar yang digunakan adalah sebesar $5,6 \%$ dan susu skim sebesar $0,1 \%$, maka penambahan lemak susu dalam perlakuan ini adalah sebesar 21,1 $\mathrm{ml} / \mathrm{L}$ $(2,11 \%)$. Perlakuan ini juga menggunakan penambahan gellan gum sebanyak 0,5\%/L (sesuai dengan prossedur Ehab et al. (2002).

Emulsi minyak jagung dalam susu skim (A2). Susu modifikasi pada perlakuan A2 adalah emulsi minyak jagung (corn oil) dalam susu skim. Modifikasi formula tersebut adalah dengan mengganti minyak kanola menggunakan minyak jagung (corn oil). Emulsi minyak jagung diperoleh dengan penggabungan antara minyak jagung sebanyak $175 \mathrm{~g} / \mathrm{L}$ susu skim ke dalam campuran emulsi dari polyoxyethylene sorbitan monostrearate (Tween-60), sorbitan monostrearate (Span-60), dan glycerol monostearate (GMS) dengan perbandingan 0,5:0,2:0,3\%. Jumlah total ketiga emulsifier tersebut adalah 19,25 g. Pembuatan emulsi minyak jagung adalah memanaskan polyoxyethylene sorbitan monostrearate (Tween-60), sorbitan monostrearate (Span60), dan glycerol monostearate (GMS) sampai tercampur sempurna. Emulsi tersebut dipanaskan kembali bersamaan dengan minyak jagung hingga suhu mencapai $60^{\circ} \mathrm{C}$. Secara terpisah susu skim yang akan digunakan dalam pembuatan keju dipanaskan hingga mencapai $60^{\circ} \mathrm{C}$. Susu skim dan emulsi minyak jagung dihomogenkan menggunakan blender, agar susu skim dan emulsi dapat 
menyatu secara sempurna, sehingga emulsi dapat terbentuk dengan baik.

Emulsi minyak jagung dalam susu skim dengan whey protein concentrate (A3). Proses modifikasi emulsi minyak jagung dalam susu skim dengan whey protein concentrate terdiri atas tiga tahap, yaitu: Tahap 1 persiapan whey protein concentrate (WPC), Sebanyak $100 \mathrm{ml}$ susu skim dipasteurisasi pada suhu $63 \pm 0,5^{\circ} \mathrm{C}$ selama 30 menit, kemudian didinginkan hingga $40^{\circ} \mathrm{C}$. Susu pasteurisasi lalu dicampurkan dengan $15 \mathrm{~g}$ WPC dengan menggunakan blender selama 1 menit. Larutan tersebut siap digunakan sebanyak $10 \mathrm{~g} / \mathrm{L}$ susu skim. Tahap 2 pembuatan emulsi minyak jagung dalam susu skim.

Proses pembuatan bahan baku dalam tahap ini serupa dengan langkah penyiapan bahan baku pada perlakuan A2. Tahap 3 pencampuran emulsi minyak jagung dalam susu skim dengan WPC, Pembuatan keju pada perlakuan $A 3$, meliputi pencampuran antara $450 \mathrm{ml}$ susu dengan perlakuan A2 dan $450 \mathrm{ml}$ susu dengan penambahan WPC. Susu yang ditambahkan WPC menggunakan gellan gum sebanyak 0,8\%/l. Pencampuran bahan tersebut dilakukan pada suhu $60^{\circ} \mathrm{C}$, agar tidak terjadi penggumpalan pada awal pencampuran. Penambahan gellan gum pada suhu di bawah $60^{\circ} \mathrm{C}$ akan menggumpalkan susu tersebut.

Modifikasi susu emulsi wow dalam susu skim (susu skim dalam emulsi $\mathrm{W}_{1} / \mathrm{O} / \mathrm{W}_{2}$ ) (A4) (Modifikasi Lobato-Calleros, 2008). Perlakuan A4 menggunakan emulsi ganda, yaitu emulsi water-in-oil-in-water multiple emulsions $\left(\mathrm{W}_{1} \mathrm{OW}_{2}\right)$. Pembuatan emulsi $\mathrm{W}_{1} \mathrm{OW}_{2}$ menggunakan inverter dengan kecepatan 1.500 rpm untuk mencampur fase air/l water (W) yang terdiri dari air, gellan gum, sorbitol, dan CMC (Carboxymethylselulose). Pengadukan dilakukan selama 10 menit. Pelarutan gellan gum dilakukan dengan menggunakan air panas $70^{\circ} \mathrm{C}$, karena gellan gum akan melarut sempurna pada suhu minimal $70^{\circ} \mathrm{C}$. Fase selanjutnya yaitu fase minyak/oil (O), fase minyak terdiri atas minyak MCT yang dicampur dengan Tween-60. Pada fase ini dilakukan homogenisasi selama 10 menit, dengan kecepatan 1.500rpm.

Fase selanjutnya adalah fase air dalam minyak/water-in-oil (WO). Fase ini terdiri atas pencampuran fase air/water (W) ke dalam fase minyak/oil (O). Pada fase ini juga dilakukan homogenisasi selama 15 menit, dengan kecepatan 1.500 rpm. Homogenisasi dengan kecepatan 11.000 rpm selama 10 menit, sehingga menghasilkan globulaglobula yang lebih kecil. Proses selanjutnya adalah pembuatan fase air dalam minyak dalam air/water-in-oil-in-water (WOW). Fase ini terdiri atas pencampuran fase air dalam minyak/water-in-oil (WO) dengan larutan biopolimer yang terdiri dari Carboxymethyl selulose (CMC). Fase WOW dihomogenisasi selama 5 menit dengan kecepatan 1.500 rpm. Hasil pencampuran WOW menghasilkan emulsi cair dan berwarna putih susu. Setelah emulsi WOW terbentuk, langkah selanjutnya adalah mencampurkannya ke dalam susu skim untuk proses pembuatan keju selanjutnya.

Emulsi minyak jagung dalam susu skim dengan penambahan probiotik (A5). Perlakuan A5 menggunakan modifikasi bahan baku sama dengan perlakuan A2 yang ditambahkan probiotik (L. casei) sebagai usaha meningkatkan sifat fungsional keju (Little et al., 2008) dan (Samuel et al., 2011) serta dapat membentuk flavor yang lebih baik (Lobato-Calleros, 2007).

\section{Prosedur penelitian}

Proses pembuatan keju putih rendah

lemak. Tahap pembuatan keju rendah lemak adalah dengan melakukan pasteurisasi susu sapi yang telah dimodifikasi pada suhu pasteurisasi $63 \pm 0,5^{\circ} \mathrm{C}$ selama 30 menit. Penambahan starter Streptococcus lactis sebanyak $1 \mathrm{ml} / \mathrm{l}$ susu skim (Akalin et al., 2007; dan Da Cruz et al., 2009) dan $\mathrm{CaCl}_{2}$ sebanyak $1,5 \mathrm{ml} / /$ susu skim pada suhu $37^{\circ} \mathrm{C}$ (Guinee, 2007). Penambahan rennet dilakukan pada suhu $37^{\circ} \mathrm{C}$. Penelitian ini menggunakan ekstraksi rennet yang berasal dari Mucor meihei. Pemilihan rennet yang berasal dari kapang dengan pertimbangan kehalalan. Rennet yang dipakai adalah rennet dari Marschall. Susu yang telah ditambah rennet dikoagulasi selama 30 menit. Setelah susu terkoagulasi sempurna dilakukan pemotongan pada curd. Tujuan pemotongan curd menurut Kelly (2007) dan Frau (2013) adalah untuk membentuk ukuran curd menjadi lebih kecil dan menyeragamkan partikel, agar whey lebih mudah keluar, meningkatkan luas permukaan curd dan tekstur curd menjadi lebih keras. Selanjutnya dilakukan proses penyaringan dan penirisan untuk memisahkan curd dengan whey dan membentuk koagulun menjadi bentuk yang lebih kompak. Curd kemudian diberi garam sebanyak $2 \%$ dari berat curd, kemudian 
dicetak sambil mengeluarkan whey selama 15 jam. Setelah diangkat dilakukan pemeraman selama 3 hari (suhu $37^{\circ} \mathrm{C}$ ) untuk dianalisis.

\section{Analisis sifat mutu fisiko kimia}

Keju putih rendah lemak dianalisis karakteristik mutunya dengan sifat fisikokimia. Sifat fisik: rendemen, tingkat kelembutan dan kekerasan (Rahmawati dan Sulmiyati, 2010). Sifat kimia meliputi: kadar air (metode oven- SNI 01-2891-1992), kadar protein (metode soxhlet- SNI 01-2891-1992), kadar abu (metode tanur -SNI 01-2891-1992), kadar fosfor (Apriyantono, 1989), kadar kalsium (Apriyantono, 1989) dan kadar lemak (metode Weibull- Standar Nasional Indonesia, 1992).

\section{Uji organoleptik}

Panelis yang terlibat sebanyak 25 orang adalah panelis semi terlatih, yaitu peneliti dan teknisi di Balai Besar Penelitian dan Pengembangan Pascapanen Pertanian, Bogor. Setyaningsih et al. (2010) menyatakan bahwa panelis semi terlatih dapat digunakan sebanyak 15-25 orang. Panelis diminta menilai mutu hedonik terhadap tiga sampel, yaitu dua sampel terpilih (A3 dan A5) dan satu sampel control (A0). Sampel merupakan keju putih rendah lemak yang diperam selama tiga hari atau disebut sebagai white fresh cheese (keju putih segar tanpa pemeraman).

\section{Mutu hedonik}

Uji mutu hedonik dilakukan untuk mengetahui tingkat kesukaan konsumen terhadap atribut warna, tekstur, aroma, rasa, kekerasan, elastisitas, dan keseluruhan. Skala yang digunakan adalah skala numerik 1-5 meliputi tingkat kesukaan terhadap warna, tekstur, aroma, rasa, kekerasan, dan elastisitas. Atribut yang digunakan meliputi warna 1-5 (sangat putih-kuning), aroma 1-5 (sangat beraroma susu-sangat harum), tekstur 1-5 (sangat halus-sangat kasar), rasa 1-5 (sangat asin-sangat asam), kekerasan 15 (sangat lembek-sangat keras), dan elastisitas 1-5 (sangat elastis-sangat tidak elastis).

\section{Rancangan percobaan dan analisis data}

Rancangan percobaan menggunakan Rancangan Acak Lengkap pola searah (Steel dan Torrie, 1989) dengan tiga kali ulangan. Data hasil uji organoleptik (hedonik/kesukaan dan mutu hedonik) dianalisis secara deskriptif meng-gunakan skor modus masing-masing perlakuan. Pengaruh perlakuan terhadap penerimaan konsumen dan pengaruh formula keju putih rendah lemak dengan berbagai bahan baku susu sapi modifikasi terhadap sifat fisik (rendemen, kelembutan, dan kekerasan) serta karakteristik sifat mutu kimia (kadar air, kadar abu, protein, lemak, kalsium, dan fosfor) dianalisis dengan uji sidik ragam (ANOVA). Jika berbeda nyata, maka analisis dilanjutkan dengan uji Duncan.

\section{Hasil dan Pembahasan}

\section{Sifat fisiko kimia keju putih rendah lemak}

Gambar 1 menunjukkan bahwa perlakuan modifikasi susu berpengaruh nyata $(P<0,05)$ terhadap rendemen keju putih rendah lemak. Perlakuan $A 1, A 3$, dan $A 5$ tidak berbeda nyata dengan nilai rendemen paling besar. Perlakuan A1 mempunyai rendemen tertinggi yaitu $16,23 \pm 0,23 \%$. Tingginya rendemen, dimungkinkan karena adanya penambahan gellan gum pada perlakuan A1. Tauer (2011) menyatakan bahwa gellan gum merupakan salah satu jenis hidrokoloid. Hidrokoloid merupakan polimer karbohidrat yang dapat diekstrak dari tanaman, rumput laut ataupun mikroba. Gellan gum adalah hidrokoloid yang berasal dari mikroba Pseudomonas oledae. Polimer karbohidrat memungkinkan dapat mengikat air lebih banyak sehingga pemisahan curd dengan whey lebih baik, artinya memperkecil kemungkinan terikutnya padatan dalam whey yang terbuang. Rendemen keju berturut-turut adalah perlakuan A3 $(15,31 \pm 0,21 \%), \quad A 5$ $(12,94 \pm 0,16 \%), \quad A 2(9,52 \pm 0,15 \%)$, dan A4 $(6,69 \pm 0,14 \%)$. Skovmose (2006) menyatakan bahwa rendemen keju yang dihasilkan umumnya sebesar 10\%. Artinya dari $10 \mathrm{~kg}$ susu segar dapat dihasilkan sebesar $1 \mathrm{~kg}$ keju segar. Salah satu faktor yang mempengaruhi rendemen keju adalah kandungan protein dan lemak susu. Skovmose (2006) menyebutkan bahwa fluktuasi kandungan protein dan lemak susu berpengaruh besar terhadap rendemen keju yang dihasilkan pada tingkat kadar air yang tetap, semakin tinggi kandungan lemak dan protein susu, maka semakin tinggi rendemen. Protein dan lemak merupakan salah satu komponen total solid yang ada di dalam susu, tampak bahwa semakin tinggi total solid dalam susu, akan menghasilkan rendemen yang semakin tinggi (González dan Zárate, 2012). Bahan dasar yang dipakai dalam pembuatan keju adalah susu skim. Susu skim tersebut dimodifikasi pada setiap perlakuan. Hal ini kemungkinan yang menyebabkan pada perlakuan susu skim 
yang ditambahkan bahan lain menghasilkan rendemen yang lebih tinggi. Tampak pada perlakuan A4 yang menggunakan susu skim mempunyai rendemen terkecil (lebih kecil 10\%) dibandingkan perlakuan lainnya.

Tingkat kekerasan. Kekerasan keju dipengaruhi oleh kadar air yang terkandung di dalamnya. Matrik yang mempunyai kadar air lebih tinggi mempunyai tekstur lebih lembut (Noronha et al., 2008). Madadlou et al. (2007) menyatakan bahwa proses homogenisasi dapat meningkatkan karakteristik tekstur, sifat fungsional, sensorik, dan rendemen keju yang dihasilkan. El-Bakri et al. (2011) menyatakan bahwa kekerasan keju rendah lemak yang tinggi dapat dikurangi dengan cara mengurangi konsentrasi $\mathrm{NaCl}$ saat pembuatan keju.

Kekerasan merupakan tekstur pada produk yang dapat dinilai secara organoleptik dengan cara menekannya menggunakan tangan atau digigit meng-gunakan gigi. Hasil analisis sifat fisik rara-rata tingkat kekerasan keju putih rendah lemak disajikan pada Gambar 2.

Berdasarkan Gambar 2, perlakuan berpengaruh nyata $(P<0,05)$ terhadap kekerasan keju putih rendah lemak. Perlakuan A1, A2, A3, dan A5 tidak berbeda nyata dengan tingkat kekerasan paling rendah. Perlakuan A5 mempunyai tingkat kekerasan yang paling

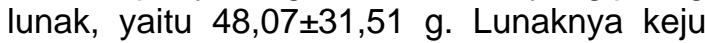
yang dihasilkan dari modifikasi susu pada perlakuan A5 dikarenakan adanya pergantian lemak susu menggunakan lemak nabati (minyak jagung). Adanya lemak dan penambahan probiotik ke dalam susu menyebabkan keju yang dihasilkan menjadi lebih lunak dibandingkan dengan perlakuan

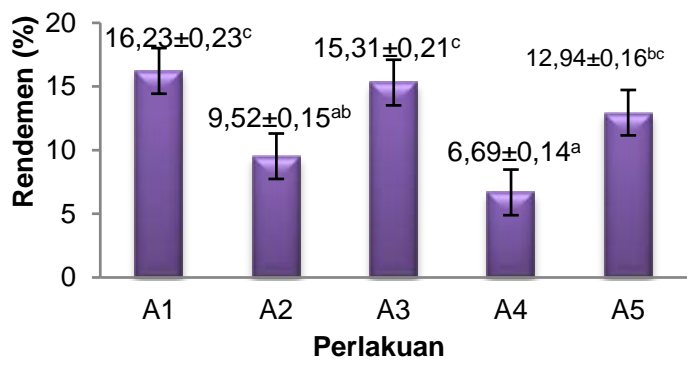

Gambar 1. Rataan rendemen keju putih rendah lemak dengan berbagai susu modifikasi (the mean of low-fat white cheese yield with a variety of modified milk).

a,b,c huruf yang berbeda pada diagram menunjukkan perbedaan yang nyata $(P<0,05)$ (the different letters in diagram show the significant difference $(P<0.05))$. yang lain. Watson dan Preedy (2010) dan Brooks et al. (2012) menyatakan bahwa probiotik dapat memecah karbohidrat (oligosakarida) yang ada di dalam keju sehingga mudah dicerna dalam sistem pencernaan. Pemecahan karbohidrat menghasilkan komponen karbohidrat dengan rantai yang lebih pendek, sehingga membuat tekstur menjadi lebih lunak. Tingkat kekerasan pada perlakuan lainnya yaitu perlakuan A1 sebesar $48,57 \pm 10,12 \mathrm{~g}, \mathrm{~A} 3$ sebesar $65,5 \pm 52,02 \mathrm{~g}$, dan A2 sebesar 95,63 $\pm 32,32$ g. Berdasarkan Gambar 2, perlakuan A4 merupakan keju putih rendah lemak yang paling keras yaitu

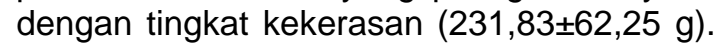
Kerasnya keju putih rendah lemak pada perlakuan A4 disebabkan oleh rendahnya kandungan lemak pada susu. Banks et al. (1989) menyatakan bahwa kadar lemak susu yang digunakan dalam pembuatan sebuah keju semakin rendah akan menghasilkan keju dengan struktur semakin keras. Susu yang digunakan pada perlakuan A4 adalah susu skim dengan kadar lemak sebesar 0,13\% dan merupakan susu sapi modifikasi yang berkadar lemak terendah dibandingkan susu sapi modifikasi pada perlakuan lainnya.

Tingkat kelembutan. Kelembutan suatu produk dihasilkan dengan cara merasakannya tekstur produk tersebut di dalam mulut. Semakin lembut tekstur suatu produk kemungkinan konsumen semakin menyukainya. Hasil analisis sifat fisik tingkat kelembutan keju putih rendah lemak disajikan pada Gambar 3. Pada Gambar 3 menunjukkan bahwa perlakuan berpengaruh nyata $(P<0,05)$ terhadap kelembutan keju putih rendah lemak. Perlakuan A5 dan A3 tidak berbeda nyata dan mempunyai tekstur

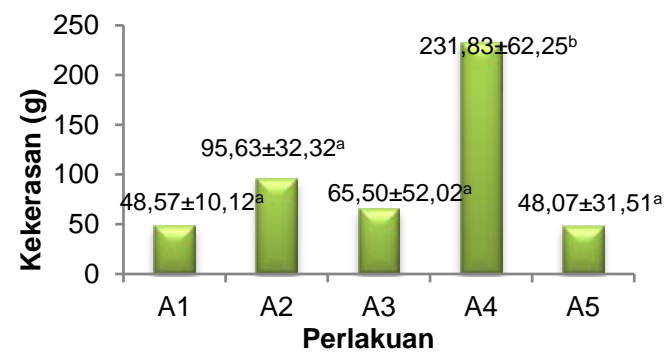

Gambar 2. Rataan tingkat kekerasan keju putih rendah lemak dengan berbagai susu modifikasi (the levels of mean of solid of low fat white cheese with various modified milk).

${ }^{a, b}$ huruf yang berbeda pada diagram menunjukkan perbedaan yang nyata $(P<0,05)$ (the different letters in diagram show the significant difference $(P<0.05)$ ). 
yang lembut. Berdasarkan tingkat kelembutan, perlakuan A3 $(9,7 \pm 1,03 \mathrm{~kg} / \mathrm{s})$ adalah paling lembut. Lembutnya keju putih rendah lemak yang dihasilkan pada perlakuan A3 diduga karena adanya penambahan gellan gum. Gellan gum mempunyai sifat dalam membuat tekstur suatu bahan makanan menjadi lebih lembut (Tauer, 2011). Kelembutan keju putih secara berturut-turut adalah A5 (8,51 $\pm 0,54 \mathrm{~kg} / \mathrm{s})$, A1 $(7,81 \pm 0,47$ $\mathrm{kg} / \mathrm{s}), A 2(5,27 \pm 1,12 \mathrm{~kg} / \mathrm{s})$, dan $\mathrm{A} 4(2,82 \pm 0,41$ $\mathrm{kg} / \mathrm{s})$.

Kadar lemak. Gambar 4 hasil analisis sifat kimia terhadap kadar lemak keju putih rendah lemak. Berdasarkan Gambar 4, tampak bahwa perlakuan berpengaruh nyata $(P<0,05)$ terhadap kadar lemak keju putih rendah lemak. Perlakuan terbaik dengan kadar lemak terendah adalah antara perlakuan A1 dan A4 yang tidak berbeda nyata. Amanda (2010) dan Rashidi et al. (2015) menyatakan bahwa kadar lemak pada keju bervariasi tergantung dari penggunaan jenis susu dan metode pembuatan. Gambar 4 menunjukkan bahwa kadar lemak terendah berdasarkan persentase berat kering, adalah perlakuan A4 dengan kadar lemak $2,63 \pm 0,43 \%$, disusul secara berturut-turut $A 1$ $(6,46 \pm 1,73 \%), \quad$ A2 $\quad(32,09 \pm 1,74 \%), \quad$ A5

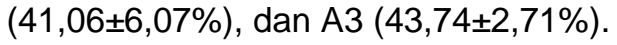

Modifikasi yang dilakukan dalam penelitian ini mengindikasikan bahwa kadar lemak susu berbeda-beda, sesuai dengan jenis modifikasi yang dilakukan. Kadar lemak pada keju yang hanya menggunakan susu skim mempunyai kadar lemak terendah (A4). Keju yang menggunakan susu diturunkan lemak sebesar 60\% (A1) mempunyai kadar lemak terendah kedua, dan perlakuan lainnya

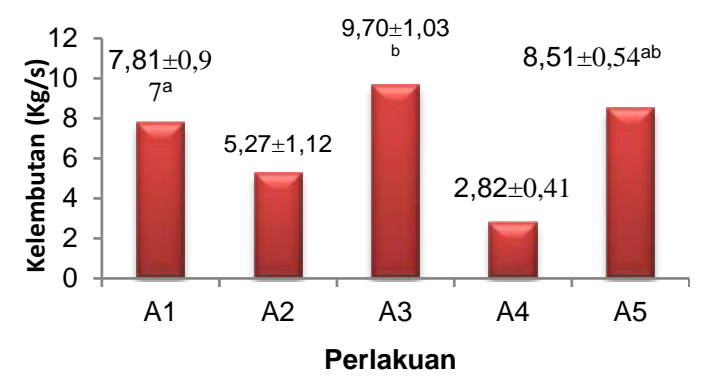

Gambar 3. Rataan tingkat kelembutan keju putih rendah lemak dengan berbagai susu modifikasi (the level of mean of low fat white cheese softness with various of modified milk).

$\mathrm{a}, \mathrm{b}$ huruf yang berbeda pada diagram menunjukkan perbedaan yang nyata $(P<0,05)$ (the different letters in diagram show the significant difference $(P<0.05))$. mempunyai nilai kadar lemak tinggi diakibatkan penggantian lemak susu dengan lemak nabati. Lemak dan minyak merupakan sumber energi yang efektif dan juga salah satu zat makanan yang penting dalam menjaga kesehatan tubuh manusia (Winarno 2008). Lemak dalam bahan pangan berfungsi untuk memperbaiki rupa dan struktur fisik bahan pangan, menambah nilai gizi, serta memberikan cita rasa gurih pada bahan pangan.

Kadar protein. Gambar 5 merupakan hasil analisis terhadap kadar protein keju putih rendah lemak. Berdasarkan Gambar 5 terlihat perlakuan berpengaruh nyata $(P<0,05)$ terhadap kadar protein keju putih rendah lemak. Kadar protein tinggi terkandung dalam keju pada perlakuan A4. Berdasarkan persentase berat kering, perlakuan A4 mempunyai kadar protein tertinggi dengan kadar sebesar $79,97 \pm 1,81 \%$. Secara berturut-turut diikuti oleh A1 $(63,80 \pm 12,58 \%), \quad$ A2 $(43,11 \pm 4,59 \%), \quad$ A5 $(37,85 \pm 3,25 \%)$, dan A3 $(29,46 \pm 7,48 \%)$. Tingginya kadar protein perlakuan A4 mengindikasikan bahwa pada saat koagulasi, kasein yang terhidrolisis lebih banyak dibandingkan dengan yang lainnya. Ana et al. (2012) melaporkan bahwa kadar protein keju pada berat kering berkisar antara 4 sampai $40 \%$, tergantung dari jenis keju yang dibuat. Amanda (2010) menyatakan bahwa kandungan protein pada keju berbanding terbalik dengan kadar lemaknya. Hal ini terlihat, bahwa keju putih yang mempunyai kadar protein yang tinggi maka akan mengandung kadar lemak rendah. Perlakuan yang mempunyai kadar protein tertinggi adalah A4 sekaligus mempunyai kadar lemak terendah.

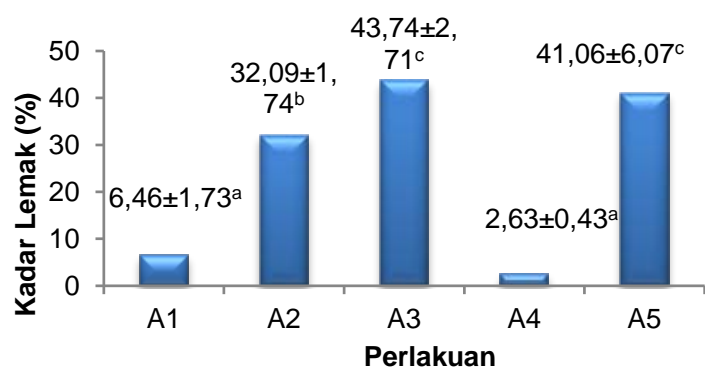

Gambar 4. Rataan persentase kadar lemak keju putih rendah lemak dengan berbagai susu modifikasi

(the mean percentage of fat white cheese with a variety of low-fat modified milk).

$a, b, c$ huruf yang berbeda pada diagram menunjukkan perbedaan yang nyata $(P<0,05)$ (the different letters in diagram show the significant difference $(P<0.05))$. 
Kadar kalsium dan fosfor. Gambar 6 merupakan hasil analisis terhadap kadar fosfor dan kalsium keju putih rendah lemak berdasarkan berat kering. Gambar 6 menunjukkan bahwa perlakuan berpengaruh nyata $(P<0,05)$ terhadap kadar fosfor keju putih rendah lemak.

Perlakuan A1, A3, dan A4 tidak berbeda nyata dan memiliki kadar fosfor yang tinggi. Perlakuan juga berpengaruh nyata $(P<0,05)$ terhadap kadar kalsium keju putih rendah lemak. Perlakuan A1, A4, A2, dan A5 tidak berbeda nyata dan merupakan perlakuan dengan kandungan kalsium tinggi.

Berdasarkan persentase berat kering kadar fosfor tertinggi adalah perlakuan $\mathrm{A} 3$, yaitu sebesar $832,15 \pm 331,75 \mathrm{mg} / 100 \mathrm{~g}$. Secara berturut-turut diikuti perlakuan $A 1$ $(644,97 \pm 158,05 \quad \mathrm{mg} / 100 \mathrm{~g}), \quad$ A4 $(633,25 \pm 142,05 \quad \mathrm{mg} / 100 \mathrm{~g}), \quad$ A2 $(483,39 \pm 19,97 \mathrm{mg} / 100 \mathrm{~g})$, dan A5 $(346,62 \pm 25,61 \mathrm{mg} / 100 \mathrm{~g})$. Fosfor berfungsi untuk koagulasi dalam susu (Habib el al., 2013; Conte et al., 2015). Berdasarkan persentase berat kering, kadar kalsium tertinggi adalah A1 dengan kadar sebesar $1.511,59 \pm 104,27 \mathrm{mg} / 100 \mathrm{~g}$, kemudian diikuti perlakuan A4 $(1.446,06 \pm 115,46 \mathrm{mg} / 100 \mathrm{~g})$, A2 $(947,86 \pm 110,21 \mathrm{mg} / 100 \mathrm{~g})$, A5 $(860,78 \pm 87,91 \mathrm{mg} / 100 \mathrm{~g})$, dan $\mathrm{A} 3$ $(695,14 \pm 131,41 \mathrm{mg} / 100 \mathrm{~g})$.

Kadar abu. Gambar 7 merupakan hasil analisis sifat kimia terhadap kadar abu keju putih rendah lemak. Gambar 7 menunjukkan bahwa perlakuan berpengaruh nyata $(P<0,05)$ terhadap kadar abu keju putih rendah lemak. Kadar abu tertinggi adalah A1 yang berbeda nyata dengan semua perlakuan lainnya. Kadar abu tertinggi berdasarkan persentase berat kering adalah perlakuan A1 sebesar $15,96 \pm 0,92 \%$ disusul secara berurut A4 $(12,09 \pm 0,17 \%), \quad$ A2 $(8,76 \pm 0,66 \%), \quad$ A3 $(8,51 \pm 0,81 \%)$, dan $A 5(7,38 \pm 1,75 \%)$. Winarno (2008) dan Magda et al. (2010) menyatakan bahwa semakin tinggi kadar abu suatu bahan makanan maka berarti bahwa kadar mineral suatu bahan semakin tinggi. Hal ini sejalan dengan hasil uji korelasi menunjukkan adanya hubungan nyata yang positif antara kadar abu dengan kadar fosfor dan kalsium sebagai mineral yang diteliti $(P<0,05)$. Mendil $(2006)$ menyatakan bahwa semakin tinggi kadar abu keju, maka kadar fosfor dan kalsium semakin tinggi. Kadar abu pada perlakuan A1 berdasarkan berat kering mempunyai nilai yang tertinggi. Hal tersebut kemungkinan karena total mineral (fosfor dan kalsium) pada perlakuan A1 mempunyai kadar abu yang tertinggi dibandingkan perlakuan lainnya. Begitupun dengan perlakuan A3 yang mempunyai kadar abu paling rendah. Total mineral pada perlakuan A3 mempunyai nilai yang terendah dibanding dengan perlakuan yang lainnya.

Kadar air. Gambar 8 berikut ini merupakan hasil analisis terhadap kadar air keju putih rendah lemak. Gambar 8 menunjukkan bahwa perlakuan berpengaruh nyata $(P<0,05)$ terhadap kadar air keju putih rendah lemak sedangkan perlakuan $\mathrm{A} 5, \mathrm{~A} 2$, dan A3 tidak berbeda nyata. Produk terbaik adalah dengan kadar air terendah agar produk dapat disimpan dalam waktu yang relatif lebih lama. Kadar air tertinggi sampai terendah, yaitu perlakuan A1 sebesar $76,64 \pm 2,52 \% \quad(\% \mathrm{~b} / \mathrm{b}), \quad \mathrm{A} 4, \quad 57,28 \pm 1,63 \%$ $(\% \mathrm{~b} / \mathrm{b}), \quad \mathrm{A} 3, \quad 55,48 \pm 4,29 \% \quad(\% \mathrm{~b} / \mathrm{b}), \quad \mathrm{A} 2$, $51,51 \pm 2,84 \%(\% \mathrm{~b} / \mathrm{b})$, dan $A 5,50,37 \pm 1,60 \%$ (\%b/b). Penggunaan gellan gum pada perlakuan A1 dimungkinkan berakibat pada tingginya kadar air keju putih rendah lemak yang diperoleh. Tauer (2011) menyatakan bahwa gellan gum merupakan salah satu jenis hidrokoloid. Ditambahkan oleh Watson dan Preedy (2010), hidrokoloid umumnya terdiri dari rantai heksosa maupun pentosa yang memiliki beberapa sisi yang memungkinkan adanya ikatan hidrogen dengan molekul air. Oleh karena itu perlakuan A1 yang ditambahkan gellan gum mempunyai kadar air yang tertinggi dibandingkan dengan perlakuan yang lainnya. Perlakuan A3 juga dilakukan penambahan gellan gum namun penambahan yang dilakukan tidak sebanyak pada perlakuan A1. Penambahan gellan gum pada perlakuan A1 sebanyak 0,5\%/L sedangkan pada perlakuan A3 sebanyak 0,4\%/L. Penambahan probiotik pada perlakuan A5 mengakibatkan rendahnya kadar air keju. Watson dan Preedy (2010) menyatakan bahwa kemampuan probiotik dalam memecah karbohidrat (oligosakarida) menjadi karbohidrat rantai pendek yang mempunyai struktur lebih kecil, memungkinkan air yang terikat pada karbohidrat menjadi terpisah menjadi air yang tidak terikat. Air tersebut terbuang bersama dengan whey pada saat penyaringan curd. 


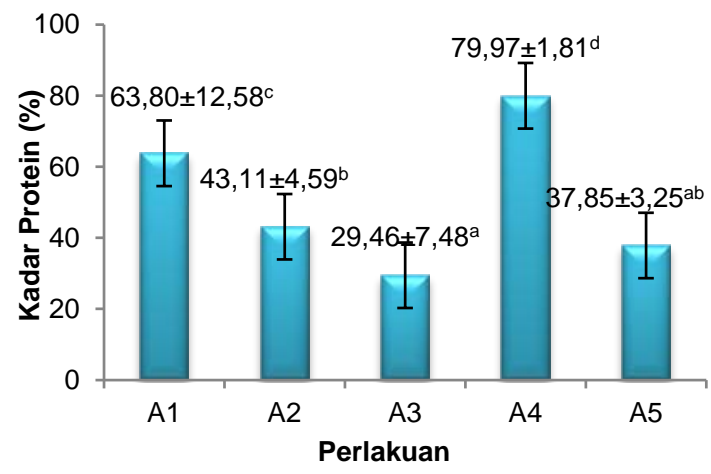

Gambar 5. Rataan persentase kadar protein keju putih rendah lemak dengan berbagai susu modifikasi

(the average of the percentage of protein content of low-fat white cheese with a variety of modified milk).

a,b,c,d huruf yang berbeda pada diagram menunjukkan perbedaan yang nyata $(P<0,05)$ (the different letters in diagram show the significant difference $(P<0.05))$

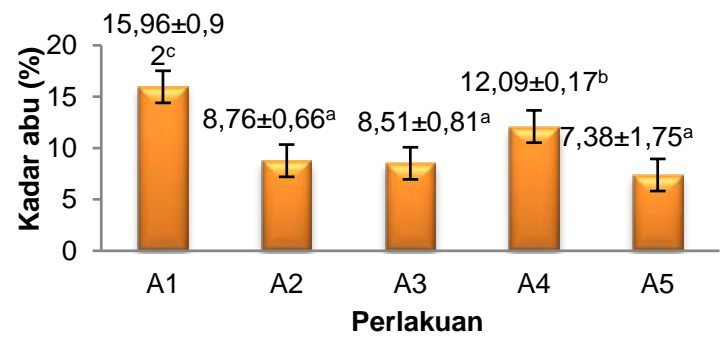

Gambar 7. Rataan persentase Kadar abu keju putih rendah lemak dengan berbagai susu modifikasi

(the average of the percentage of ash content of low-fat white cheese with a variety of modified milk).

a,b,c huruf yang berbeda pada diagram menunjukkan perbedaan yang nyata $(P<0,05)$ (the different letters in diagram show the significant difference $(P<0.05))$.

Sifat organoleptik. Kulmyrzaev et al. (2005) dan Ong et al. (2007) tekstur menyatakan bahwa kekerasan dan kelembutan merupakan parameter penting dalam evaluasi kualitas keju. Hal tersebut dikarenakan refleksi dari struktur keju tingkat mikroskopis dan molekul. Produk yang terpilih adalah produk yang mempunyai rendemen tertinggi, kelembutan tertinggi dengan kekerasan terendah, yaitu A3 dan A5. Kedua produk terpilih selanjutnya dibandingkan dengan kontrol. Kontrol merupakan keju putih yang berasal dari susu whole milk (A0).

Warna. Penentuan mutu bahan makan-an pada umumnya sangat bergantung pada beberapa faktor di antaranya cita rasa, warna, tekstur dan nilai gizinya (Karagozlu et al., 2009). Suatu bahan yang dinilai bergizi,

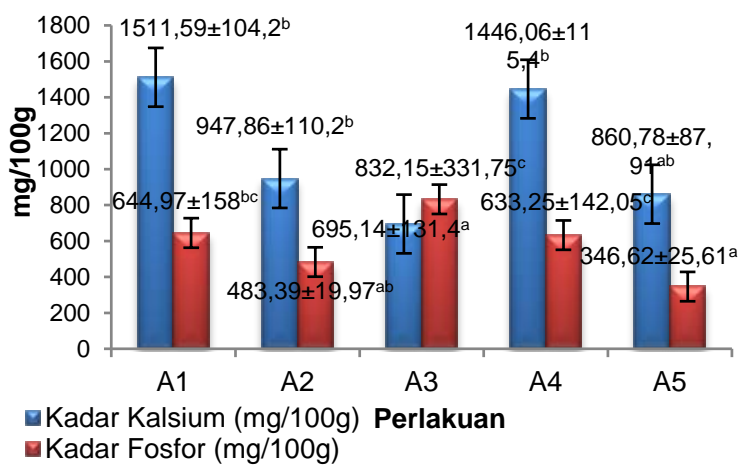

Gambar 6. Rataan kadar fosfor dan kadar kalsium keju putih rendah lemak dengan berbagai susu modifikasi

(the mean of phosphorus and calcium content of low-fat white cheese with a variety of modified milk).

a,b,c huruf yang berbeda pada diagram menunjukkan perbedaan yang nyata $(P<0,05)$ (the different letters in diagram show the significant difference $(P<0.05))$.

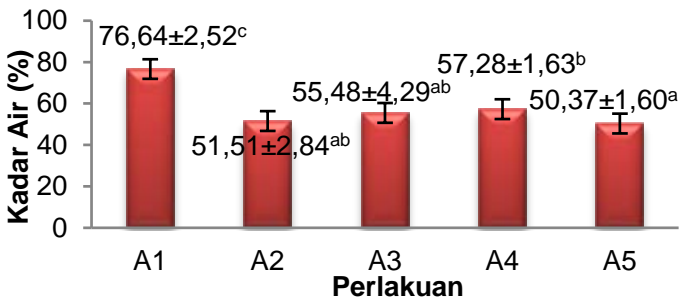

Gambar 8. Rataan persentase kadar air keju putih rendah lemak dengan berbagai susu modifikasi

(the average of the percentage of moisture content of low-fat white cheese with a variety of modified milk).

a,b,c huruf yang berbeda pada diagram menunjukkan perbedaan yang nyata $(P<0,05)$ (the different letters in diagram show the significant difference $(P<0.05)$ )

enak dan teksturnya sangat baik tidak akan dimakan apabila memiliki warna yang tidak sedap dipandang atau memberikan kesan telah menyimpang dari warna yang seharusnya (Setyaningsih et al., 2010). Berdasarkan Gambar 9 tampak bahwa perlakuan berpengaruh nyata $(P<0,05)$ terhadap kesukaan panelis pada atribut warna keju putih rendah lemak. Warna keju perlakuan A6 tidak berbeda nyata perlakuan A4, namun berbeda nyata dengan perlakuan A0. Nilai rerata penilaian organoleptik terhadap kesukaan warna keju putih rendah

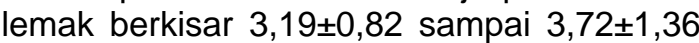
(biasa hingga suka). Warna keju akan semakin disukai apabila nilai rerata semakin tinggi. Panelis menyukai perlakuan AO sedangkan untuk perlakuan A3 dan A5 
panelis menyatakan biasa pada warna keju yang dihasilkan.

Perlakuan berpengaruh nyata $(P<0,05)$ terhadap mutu warna keju putih rendah lemak. $\mathrm{Hal}$ ini menunjukkan bahwa perlakuan mempengaruhi penampakan warna keju putih rendah lemak. Warna pada perlakuan A3 tidak berbeda nyata dengan A5 dan semua perlakuan berbeda nyata dengan AO. Gambar 9 menunjukkan bahwa warna keju putih rendah lemak memiliki nilai rataan putih hingga putih

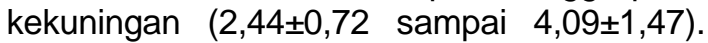
Perlakuan A0 mempunyai warna putih kekuningan, sedangkan perlakuan A3 dan A5 mempunyai warna putih. Berdasarkan hasil uji organoleptik terhadap warna, keju putih kontrol mempunyai warna putih kekuningan dan disukai oleh panelis. Perlakuan A3 dan A5 mempunyai warna putih dan panelis menilai pada taraf biasa terhadap warna keju putih yang dihasilkan.

Tekstur. Mutu tekstur sangat penting dalam menilai mutu keju (Madadlou et al., 2007) dan (Francisco et al., 2012). Gambar 10 menunjukkan bahwa perlakuan tidak berpengaruh nyata $(P>0,05)$ terhadap kesukaan panelis pada atribut tekstur keju putih rendah lemak. Nilai rerata yang semakin rendah menunjukkan tekstur keju putih rendah lemak yang semakin kurang disukai. Semakin halus (lembut) tekstur nilai rerata tekstur semakin naik, artinya semakin halus (lembut) tekstur keju putih rendah lemak semakin disukai oleh panelis (Yates dan Drake, 2007). Pada Gambar 10 bahwa perlakuan berpengaruh nyata $(P<0,05)$ terhadap mutu tekstur keju putih rendah lemak dan memiliki tekstur halus (lembut) hingga biasa, yaitu pada kisaran $2,53 \pm 1,13$ sampai $3,56 \pm 0,82$. Perlakuan A3 tidak berbeda nyata dengan A5 dan semua

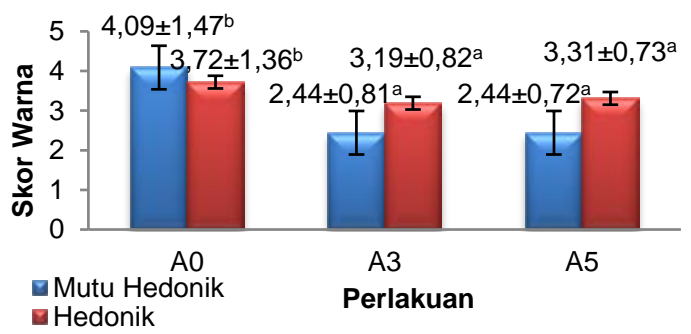

Gambar 9. Rataan pengaruh perlakuan terhadap warna keju putih rendah lemak

(the mean of treatment effect to low-fat white cheese color).

$a, b$ huruf yang berbeda pada batang dengan warna yang sama menunjukkan perbedaan nyata $(P<0,05)$ (the

different letters on the same color bars show significant differences $(P<0.05))$. perlakuan berbeda nyata dengan A0. Berdasarkan uji organoleptik terhadap atribut tekstur, keju putih pada perlakuan A0, A3 dan A5 mempunyai tekstur kasar dan panelis memilih pada taraf biasa dan nilai rerata $2,88 \pm 1,08$ sampai $3,28 \pm 0,92$ atau berada pada kisaran biasa.

Aroma. Aroma adalah bau yang ditimbulkan oleh rangsangan kimia yang tercium oleh syaraf-syaraf olfaktori yang berada dalam rongga hidung (Vincent et al., 2015). Berikut ini merupakan rerata hasil uji organoleptik terhadap aroma keju putih rendah lemak.

Berdasarkan Gambar 11, perlakuan tidak berpengaruh nyata $(P>0,05)$ terhadap tingkat kesukaan panelis pada atribut aroma keju putih rendah lemak. Semakin harum aroma keju putih rendah lemak nilai rerata aroma semakin naik, dengan kata lain semakin harum aroma keju putih rendah lemak semakin disukai oleh panelis. Panelis semakin suka terhadap aroma keju jika nilai rerata semakin tinggi. Gambar 11 menunjukkan bahwa perlakuan tidak berpengaruh nyata $(P>0,05)$ terhadap mutu aroma keju putih rendah lemak. Hal ini menunjukkan bahwa perlakuan tidak mem-pengaruhi aroma keju putih rendah lemak dengan kisaran nilai $2,59 \pm 0,40$ sampai 2,66 $\pm 0,10$ (beraroma susu hingga netral (tidak beraroma)). Aroma keju pada ketiga perlakuan adalah netral (tidak beraroma) dan nilai kesukaan panelis adalah pada taraf biasa dengan nilai $2,88 \pm 0,21$ sampai $3,28 \pm 0,15$, berada pada kisaran biasa.

Rasa. Rasa ialah sugesti kejiwaan terhadap makanan yang menentukan nilai pemuasan orang yang memakannya (Dilek et al., 2012). Mutu rasa merupakan faktor yang sangat penting dalam menentukan keputusan akhir konsumen untuk dapat menerima atau

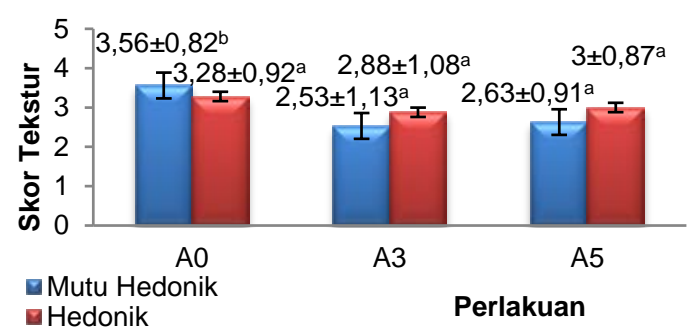

Gambar 10. Rataan pengaruh perlakuan terhadap tekstur keju putih rendah lemak

(the mean of treatment effect to the texture of lowfat white cheese).

huruf yang sama pada batang dengan warna sama menunjukkan tidak ada perbedaan yang nyata $(P>0,05)$ (the same letters on the same color bars show there is no significant differences $(P>0.05)$ ). 
menolak suatu produk walaupun atribut penilaian yang lain baik, tetapi jika rasa tidak enak maka produk akan segera ditolak oleh konsumen (Pastor et al., 2008; Florencia et al., 2014). Nilai rerata uji mutu hedonik rasa pada setiap perlakuan dapat dilihat pada Gambar 15.

Tampak pada Gambar 12 bahwa perlakuan tidak berpengaruh nyata $(P>0,05)$ terhadap kesukaan panelis mengenai atribut rasa keju putih rendah lemak. Nilai rerata penilaian uji hedonik terhadap atribut rasa keju putih rendah

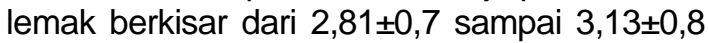
(biasa). Nilai rerata yang semakin rendah menunjukkan kesukaan panelis terhadap rasa keju putih rendah lemak semakin kurang suka. Berdasarkan Gambar 12 perlakuan berpengaruh nyata $(P<0,05)$ terhadap mutu rasa keju putih rendah lemak. Hal ini menunjukkan bahwa perlakuan berpengaruh terhadap rasa keju putih rendah lemak. Perlakuan A5 dan A0 mempunyai rasa yang tidak berbeda nyata yaitu asin dengan nilai $1,88 \pm 0,1$ sampai $2,16 \pm 0,3$ (asin). Sedangkan A5 tidak berbeda nyata dengan A3 dengan nilai

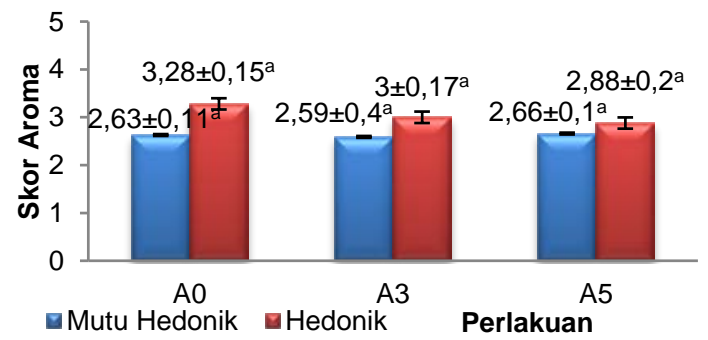

Gambar 11. Rataan pengaruh perlakuan terhadap aroma keju putih rendah lemak

(the mean of treatment effect to low fat white cheese aroma).

huruf yang berbeda pada batang dengan warna sama menunjukkan perbedaan nyata $(P<0,05)$ (the different letters on the same color bars show significant differences $(P<0.05))$

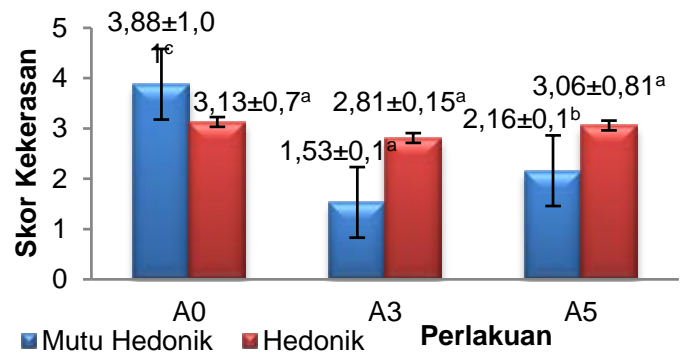

Gambar 13. Rataan pengaruh perlakuan terhadap kekerasan keju putih rendah lemak (the mean of treatment effect to low-fat solid white cheese).

$a, b, c$ huruf yang berbeda pada batang dengan warna yang sama menunjukkan perbedaan yang nyata $(P<0,05)$ (the different letters on the same color bars show significant differences $(P<0.05)$ ).
1,59 $\pm 0,1$ sampai $1,88 \pm 0,1$ (mendekati sangat asin).

Kekerasan. Berikut ini merupakan rerata hasil uji organoleptik terhadap kekerasan keju putih rendah lemak. Gambar 13 menunjukkan bahwa perlakuan tidak berpengaruh nyata $(P>0,05)$ terhadap kesukaan panelis pada atribut kekerasan keju putih rendah lemak. Semakin rendah nilai rerata menunjukkan kesukaan panelis terhadap kekerasan keju putih rendah lemak semakin berkurang. Semakin lembek atau lembut tingkat kekerasan keju putih rendah lemak nilai rataan semakin naik, artinya semakin lembut semakin disukai oleh panelis. Nilai rerata penilaian uji hedonik (kesukaan) terhadap parameter kekerasan keju putih

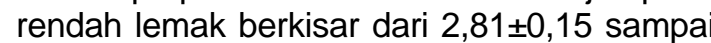
$3,13 \pm 0,7$ atau berada pada kisaran biasa Berdasarkan Gambar 13, perlakuan berpengaruh nyata $(P<0,05)$ terhadap mutu kekerasan keju putih rendah lemak. Perlakuan A3 mempunyai tekstur paling lembut dan berbeda nyata dengan semua perlakuan.

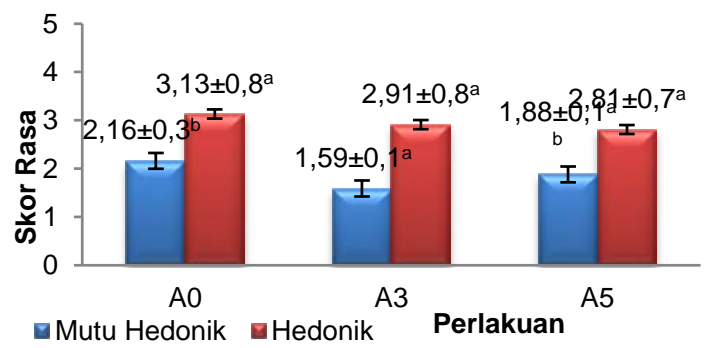

Gambar 12. Rataan pengaruh perlakuan terhadap rasa keju putih rendah lemak

(the mean of treatment effect to low-fat white cheese flavor).

${ }^{a, b}$ huruf yang berbeda pada batang dengan warna sama menunjukan perbedaan yang nyata $(P<0,05)$ (the different letters on the same color bars show significant difference) $(P<0.05))$.

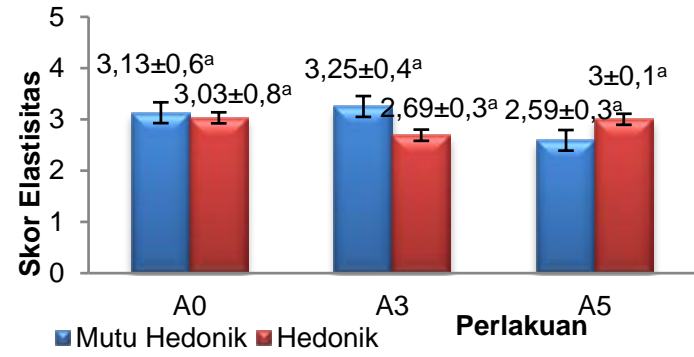

Gambar 14. Rataan pengaruh perlakuan terhadap elastisitas keju putih rendah lemak

(the mean of treatment effect to the elasticity of low-fat white cheese).

huruf yang sama pada batang warna sama menunjukan tidak ada perbedaan yang nyata $(P>0,05)$ (the same letters on the same color bars showe is no significant differences $(P>0.05)$ ). 
Nilai rerata kekerasan keju putih rendah lemak berkisar antara 1,53 $\pm 0,13$ sampai $3,88 \pm 1,01$. Uji organoleptik menunjukkan bahwa perlakuan AO memiliki tekstur keras dan tingkat kesukaan pada taraf biasa. Perlakuan A3 dan A5 mempunyai tekstur biasa tingkat kesukaan biasa.

Elastisitas. Elastisitas merupakan ukuran penting terhadap mutu keju (Hee et al., 2015). Gambar 14 merupakan rerata hasil uji organoleptik terhadap elastisitas keju putih rendah lemak.

Gambar 14 menunjukkan bahwa perlakuan tidak berpengaruh nyata $(P>0,05)$ terhadap kesukaan panelis mengenai atribut elastisitas keju putih rendah lemak. Nilai rerata penilaian uji hedonik terhadap atribut elastisitas keju putih rendah lemak berkisar dari 2,69 $\pm 0,3$ sampai 3,03 $\pm 0,8$ (kisaran biasa). Nilai rerata yang semakin rendah menunjukkan kesukaan panelis terhadap elastisitas keju putih rendah lemak semakin kurang suka. Semakin elastis tingkat elastisitas keju putih rendah lemak nilai rerata elastisitas semakin naik atau semakin elastis tingkat elastisitas keju putih rendah lemak semakin disukai oleh panelis. Berdasarkan Gambar 14, perlakuan tidak berpengaruh nyata $(P>0,05)$ terhadap mutu elastisitas keju putih rendah lemak. Berdasarkan uji mutu hedonik, rentang elastisitas pada keju putih rendah lemak yang dihasilkan adalah

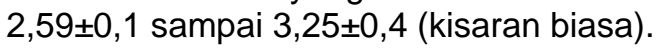

\section{Kesimpulan}

Keju putih rendah lemak dapat dibuat dengan berbagai jenis bahan baku susu modifikasi. Karakteristik mutu keju putih rendah lemak terbaik adalah keju yang mempunyai rendemen tertinggi, tekstur paling lembut dan paling lunak serta daya terima paling tinggi. Perlakuan yang terpilih adalah modifikasi susu skim dalam emulsi minyak jagung yang ditambahkan probiotik yaitu, mempunyai rendemen $12,94 \pm 0,16 \%$, tingkat kekerasan 48,07 $\pm 10,12 \mathrm{~g}$, tingkat kelembutan

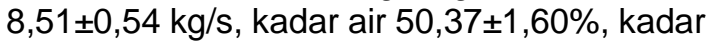
abu $7,38 \pm 1,75 \%$ (bk), kadar lemak $41,06 \pm 6,07 \% \quad$ (bk), kadar protein $37,85 \pm 3,25 \%$ (bk), kadar fosfor 346,62 $\pm 24,61$ mg/100g (bk), kadar kalsium 860,78 $\pm 87,91$ $\mathrm{mg} / 100 \mathrm{~g}$ (bk), berwarna putih, tekstur biasa, tidak beraroma, mempunyai rasa asin, lembut, elastisitas biasa, dan tingkat kesukaan biasa, sesuai SNI 01-2980-1992.

\section{Ucapan Terima Kasih}

Terima kasih kepada saudari Maulidayanti, alumni Fakultas Ekologi Manusia, IPB Bogor dan M Wahyudi, teknisi Balai Besar Litbang Pascapanen Pertanian, Bogor yang telah membantu kegiatan peneltian ini.

\section{Daftar Pustaka}

Abdulmalek, M. A. and A. A. Abdulaziz. 2011. Microbiological Changes and Determination of Some Chemical Characteristics for Local Yemeni Cheese. Jordan J. Biol. Sci. 4: 93-100.

Akalin, A. S., S. Gonc, G. Unal, and S. Fenderya. 2007. Effects of fructooligosacharide and WPC on the viability of starter culture in reduce-fat probiotic yogurt during storage. J. Food Sci. 72: 222-227.

Amanda, R. D. 2010. Uji aktivitas rennet dari abomasums kambing lokal muda pada kondisi yang berbeda dan karakterisasi keju yang dihasilkan. Skripsi Fakultas Peternakan, Institut Pertanian, Bogor Bogor.

Ana, P. L. D., C. C. P. de Andrade, F. Mandelli, R. C. de Almeida and S. Echeverrigaray. 2012. Microbiological, physico-Chemical and sensorial characteristics of serrano, an artisanal brazilian cheese. Food and Nutr Sci.3: 1068-1075.

Apriyantono, A. 1989. Analisis Pangan. IPB Press, Bogor.

Banks, J. M., E. Brechany and W. W. Christie. 1989. The production of low fat cheddar type cheeses. J. of the Society of Dairy Technology 42: 6-9.

Brooks, J. C., B. Martinez., J. Stratton. A. Bianchini. R. Krokstromb and R. Hutkins. 2012. Survey of raw milk cheeses for microbiological quality and prevalence of foodborne pathogens. Food Microbiol. 31: 154-158.

Conte, F., A. Ravidà, A. Mandanici, V. Ferrantelli, M. Chetta and A. Verzera. 2015. Maiorchino cheese: physicochemical, hygienic and safety characteristics Italian J. Food safety. 4: 27-32.

Da Cruz, A. G., F. C. A Buriti, C. H. B de Sauza, J. A. F. Fonseca, and S. M. I. Saad. 2009. Probiotic cheese: health 
benefits, technological and stability aspects. J. Trends Food Sci. Technol. 20: 344-354.

Dilek, B., B. K. Yasemin and U. Gokhan. 2012. Determination of some traces metal levels in cheese samples packaged in plastic and tin containers by ICP-OES after dry, wet and microwave digestion. Food and Chem Toxicol. 49: 202-20.

Ehab, A. R., A. Michaelidou, C. G. Biliaderis and G. K. Zerfiridis. 2002. Low fat white-brined cheese made from bovine milk and two commercial fat mimetics: chemical, physical and sensory attributes. Int. Dairy J. 12: 525-540.

El-Bakry, M., F. Beninati, E. Duggan, E. D. O'Riordan, M. O'Sullivan 2011. Reducing salt in imitation cheese: effects on manufacture and functional properties. J. Food Res. Int. 44: 589596.

Florencia, F., G. F. de Valdez and N. Pece. 2014. Effect of pasteurization temperature, starter culture, and incubation temperature on the physicochemical properties, yield, rheology, and sensory characteristics of spreadable goat cheese. J. Food Proc. Vol. 2014

Francisco, J. D., G. C. José. C. Ramón and R. Rosario. 2012. Changes in microbiology, proteolysis, texture and sensory characteristics of raw goat milk cheeses treated by high-pressure at different stages of maturation. Food Sci. and Technol. 48: 268-275.

Frau, F. 2013. Rheology of spreadable goat cheese made with autochthonous lactic cultures differing in their ability to produce exopolysaccharides. Food Sci and Technol 33: 233-238.

González, L. and V. Zárate. 2012. Influence of an autochthonous starter culture and a commercial starter on the characteristics of Tenerife pasteurised goats' milk cheese. Int. J. Dairy Technol. 65: 542-547.

Guinee, T. P., B. O'Brien, E. O. Mulholland. 2007. The suitability of milk from a spring-calved dairy herd during the transition from normal to very late lactation for the manufacture of low moisture Mozzarella cheese. Int. Dairy. J. 17: 133:142.

Habib, M. T., Q. A. Nogaim, T. A. Alazaze, Y. S. Alabadli and S. A. Aon. 2013. Microbiological characteristics and mineral content of local smoked cheese produced in Yemen. J. Food Nutr. Sci. 1: 65-71.

Hee, Y. C., C. J. Yang, K. S. Choi and I. Bae. 2015. Characteristics of gouda cheese supplemented with fruit liquors. J. Anim. Sci. and Technol. 57: 15.

Karagozlu, C., S. Kilic and N. Akbulut. 2009. Some characteristics of cimi tulum cheese from producting goat milk .Bulgarian J. Agric. Sci. 15: 292-297.

Kelly, A. L. 2007. What are the compositions of other species' milks and how does this affect their cheesemaking properties. cheese problem solved. CRC Press, New York.

Kulmyrzaev, A., E. Dufour, Y. Noel, M. Hanafi, R. Karoui, E. M. Qannari, G. Mazerolles. 2005. Investigation at the molecular level of soft cheese quality and ripening by infrared and fluorescence spectroscopies and chemometrics-relationships with rheology properties. Int. Dairy J. 15: 669-687.

Little, C. L., J. R. Rhoades, S. K. Sagoo, J. Harris, Greenwood and V. Mithani. 2008. Microbial quality of retail cheese made from raw, thermised or pasteurized milk in UK. Food Microbiol. 25: 304-312.

Lobato-Calleros, C. 2007. Microstructure and texture of white fresh cheese made with canola oil and whey protein concentrate in partial or total replacement of milk fat. J. Food Res. Int. 40: 529-537.

Lobato-Calleros, C. 2008. Structural and textural characteristics of reduced-fat cheese-like products made from W1/O/W2 emulsions and skim milk. J. Food Sci. Technol. 41: 1847-1856.

Madadlou, A., M. E. Mousavi, A. K. Asl, Z. Emam-Djome and M. Zargaran. 2007. Effect of cream homogenization on textural characteristic of low-fat Iranian white cheese. Int. Dairy J. 17: 547-554.

Madadlou, A., M. E. Mousavi, A. K. Asl, Z. Emam-Djome, and M. Zargaran. 2007. Effect of cream homogenization on textural characteristic of low-fat Iranian white cheese. Int. Dairy J. 17: 547-554.

Magda, M. A., N. A. Madeha, Y. Q. Safaa, M. El-Sawi and Nagwa. 2010. Mineral content and microbiological examination of some white cheese in Jeddah. Food and Chem. Toxicol. 48: 3031-3034. 
Mendil, D. 2006. Mineral and trace metal levels in some cheese collected from Turkey. Food Chem. 96: 532-537.

Noronha, N., E. Duggan, G. R. Ziegler, E. D. O'Rirdan, and M. O'Sullivan. 2008. Inclusion of starch in imitation cheese, its influence on water mobility and cheese functionality. J. Food Hydrocol. 22: 1613-1621.

Ong, L., A. Henriksson, and N. P. Shah. 2007. Chemical analysis and sensory evaluation of cheddar cheese produced with Lactobacillus acidophilus, Lb. casei, Lb. paracasei or Bifidobacterium sp. Int. Dairy J. 17: 937-945.

Pastor, L. F. J., B. M. Mellado, A. A. Ramirez and R. E. Dolores. 2008. Sensory evaluation of goatmilk cheese type boursin natural and ash flavor, Revista Electrónica de Veterinaria, 9: 16957504.

Rahmawati, M. and Sulmiyati. 2010. Karakteristik fisik dan organoleptik keju markisa dengan pemberian level starter (Lactococcus lactissubsp. lactis 527) dengan lama pemeraman yang berbeda. Prosiding Seminar Nasional Teknologi Peternakan dan Veteriner, Pusltbang Peternakan, Bogor.

Rashidi, H. M. Mazaheri-Tehrani. M. A. Razavi; M. Ghods-Rohani.2015, Improving Textural and Sensory Characteristics of Low-Fat UF Feta Cheese Made with Fat Replacers. J. Agricultural Sci. Technol. 17: 121-132.

Samuel, M., L. Eric, G. Frédéric, C. Nadia and Pierre-B Marie. 2011. Trace metals in raw cows' milk. A survey on the microbiological quality of Carra, a traditional Turkish cheese. J. Food Eng. 66: 401-404.
San, M. G., J. J. Rodríguez, S. Gurram, S. Clark, B. G. Swanson, and G. V. Barbosa-Cánovas. 2007. Yield, composition and rheological characteristics of cheddar cheese made with high pressure processed milk. Food Sci. Technol. 40: 697-705.

Setyaningsih, D. and A. Apriyantono, M. P. Sari. 2010. Analisis sensori untuk industri pangan dan agro. IPB Press, Bogor.

Skovmose, E. 2006. Cheese yield facts.http://www.danlac.com/news/che ese-yield-facts. Accessd 2 Agustus 2015.

Standar Nasional Indonesia. 1992. SNI: 012891-1992 Cara uji makanan dan minuman. Dewan Standar Nasional Indonesia, Jakarta.

Steel, R. G. D and J. H. Torrie. 1989. Prinsip dan prosedur statistika - suatu pendekatan biometrik. PT. Gramedia, Jakarta.

Tauer, K. 2011. Emulsions, MPI colloids and interfaces. Am Muhlenberg, Jerman.

Vincent, B., N. Power, Y. Pouliot and M. Britten. 2015. Relationship between baked cheese sensory properties and melted-cheese physical characteristics. J. Texture Stud. 46: 321-334.

Watson, R. R and V. R. Preedy. 2010. Bioactive foods in promoting health probiotics and probiotics. San Diego: Elsevier Inc.

Winarno, F. G. 2008. Kimia pangan dan gizi. Gramedia Pustaka Utama, Jakarta.

Yates, M. D and M. A. Drake. 2007. Texture properties of gouda cheese. J. Sensory Stud. 22: 493-506. 